\title{
Overview of Pavement Materials and Operation Phases for the Minnesota Road
}

\author{
Shuang LI \\ School of Highway, Chang'an University, Xi'an 710064, \\ China \\ Beijing 100088, China \\ e-mail: 1406118621@qq.com
}

\author{
Xin-jun LI \\ School of Highway, Chang'an University, Xi'an 710064, \\ China \\ Key Laboratory of Road Structure \&Materials Ministry \\ of Communications \\ Beijing 100088, China \\ e-mail: leexinjun@gmail.com
}

\author{
Zhen-gang FENG ${ }^{*}$ \\ School of Highway, Chang'an University, Xi'an 710064, \\ China \\ Beijing 100088, China \\ e-mail: zgfeng@chd.edu.cn \\ Pei-long LI \\ School of Highway, Chang'an University, Xi'an 710064, \\ China; \\ Beijing 100088, China \\ lipeilong@chd.edu.cn
}

\begin{abstract}
Asphalt pavement is easily suffered from early damage under exposure to the natural environment. Regular pavement performance monitoring is mostly based on laboratory test, which could not simulate the actual pavement conditions effectively. Thus it is significant to develop an accelerated test facility. American Minnesota Road (MnROAD) is one of the complex and accelerated test roads in the world, aiming to develop and advance pavement design, operation and maintenance methods both for the highway and low volume road in extreme cold regions. The test cells and pavement materials of the MnROAD during different phases were introduced. Achievement obtained from the MnROAD will provide experience on new-generation pavement materials and design method, which will have positive impact on the development of pavement engineering.
\end{abstract}

Keywords-Minnesota Road; Pavement Materials; Operation Phases; Pavement Design.

\section{BACKGROUND}

Asphalt pavement is gradually influenced by vehicle load, temperature, humidity and many other combined factors, which causes fatigue, rutting, cracking and other early damage, seriously degrading pavement service performance[1]. However, the existing pavement research methods are mostly based on laboratory test and it is difficult to simulate the actual pavement conditions. Thus it is important to develop an accelerated test road. The MnROAD is a cold region full-scale accelerated pavement test facility, constructed by the Minnesota Department of Transportation (MnDOT) during 1990-1993[2]. Since 1994, MnDOT has cooperated with Minnesota Local Road Research Board (LRRB), state DOTs, the Federal Highway Administration (FHWA), industry, universities and international organizations to conduct projects on MnROAD related to pavement materials and design, construction techniques, pavement performance and pavement maintenance[3]. However, the construction and operation experience of full-scale test road is lacked and not widely applied in China at present. Taken the MnROAD as an example, pavement materials selection and different operation phases of the MnROAD were summarized in this paper, which could provide guidance for the pavement structure design and performance improvement.

\section{TEST SECTIONS AND PAVEMENT MATERIALS OF THE MNROAD}

The MnROAD was located near Albertville, Minnesota with traffic opening in 1994. The MnROAD consisted of three proportions that were divided into 55 test cells. Each test cell was approximately 500 feet long, representing different combinations of the road-building materials and design structures. The 3.5-mile Mainline (ML) was part of west-bound I-94 between Albertville and Monticello, which carrying "live" traffic averaging 28,500 vehicles per day with $12.4 \%$ trucks. The two-lane roadway contained 31 cells. The cell maps of the ML roadway are shown in Fig. 1. The Farm Loop was constructed in 2007 to test the effect of heavy farm equipment on pavement performance, located in the MnROAD stockpile area. It consisted of two test cells (83 and 84), aiming to evaluate the influence of heavy farm vehicles on low volume $\operatorname{roads}^{[3]}$. The 2.5-mile Low Volume Road (LVR) was parallel and close to the Mainline, carrying a MnROAD-operated 18-wheel, a controlled 5-axle, 80,000-lb tractor-semi-trailer to simulate conditions of rural roads. The two-lane closed loop contained 24 cells $^{[4]}$. The cell maps of the LVR are shown in Fig. 2. 


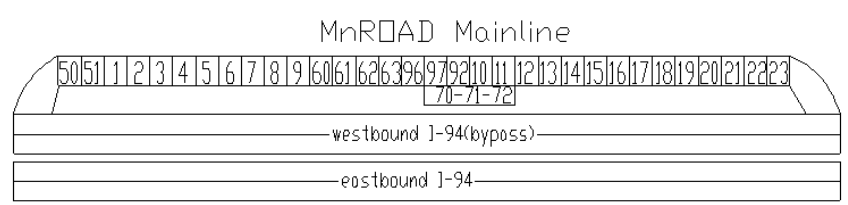

Fig. 1 The cell maps of Mainline (ML)

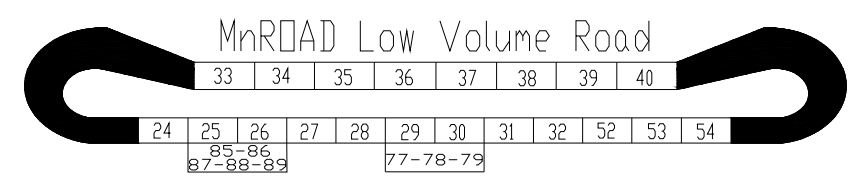

Fig. 2 The cell maps of Low Volume Road (LVR)

The various types of pavement surface materials used on the MnROAD Mainline (ML) and Low Volume Road (LVR) were summarized and listed in Table 1 and 2, respectively. For the purpose of monitoring performance variation of these pavement materials, MnROAD has installed over 9000 sensors at present. There are generally two different kinds of pavement sensors: static sensors (measure environmental factors) and dynamic sensors (measure traffic loadings). The dynamic pavement response sensors induced by the passing of heavy vehicles, could acquire data up to 2000 times per second while the static sensors only capture environmental data every 15 minutes. Dynamic sensors include Linear Variable Differential Transformer (LVDT), concrete embedment strain gauge, steel strain gauge, dynamic soil pressure cell and bituminous strain gauge. Static sensors include horizontal clip gauge, moisture gauge, thermocouple, resistivity probe, tipping bucket and vibrating wires ${ }^{[5]}$. These sensors could be used to measure the stress and strain in the horizontal and vertical directions, temperature, humidity and so on in different depth of pavement structure. An extensive data collection system attained by the embedded electronic sensors could be used to study how traffic loadings and environmental conditions affect pavement materials and performance over time ${ }^{[2]}$.

TABLE 1. SUMMARY OF PAVEMENT SURFACE MATERIALS ON THE MNROAD MAINLINE (ML)

\begin{tabular}{|c|c|c|c|}
\hline $\begin{array}{l}\text { Test } \\
\text { number }\end{array}$ & Material type & $\begin{array}{l}\text { Test } \\
\text { number }\end{array}$ & Material type \\
\hline Cell 50 & $\begin{array}{l}\text { SUPERPAVE hot mix } \\
\text { asphalt (HMA) }\end{array}$ & Cell 51 & SUPERPAVE HMA \\
\hline Cell 1 & Original HMA & Cell 2 & $\begin{array}{l}\text { Stabilized full depth } \\
\text { reclamation }\end{array}$ \\
\hline Cell 3 & $\begin{array}{l}\text { Stabilized full depth } \\
\text { reclamation }\end{array}$ & Cell 4 & $\begin{array}{l}\text { Stabilized full depth } \\
\text { reclamation }\end{array}$ \\
\hline $\begin{array}{l}\text { Cell } \\
305-605\end{array}$ & $\begin{array}{l}\text { Unbonded concrete } \\
\text { overlay }\end{array}$ & $\begin{array}{l}\text { Cell } \\
306-406\end{array}$ & Concrete initiatives \\
\hline Cell 7 & Original concrete & Cell 8 & Original concrete \\
\hline Cell 9 & Original concrete & Cell 60 & Whitetopping \\
\hline Cell 61 & Whitetopping & Cell 62 & Whitetopping \\
\hline
\end{tabular}

\begin{tabular}{|c|c|c|c|}
\hline Cell 63 & Whitetopping & Cell 96 & Whitetopping \\
\hline Cell 70 & $\begin{array}{l}2009 \text { SHRP-II Composite } \\
\text { pavements }\end{array}$ & Cell 71 & $\begin{array}{l}2009 \text { SHRP-II Composite } \\
\text { pavements }\end{array}$ \\
\hline Cell 72 & $\begin{array}{l}2009 \text { SHRP-II Composite } \\
\text { pavements }\end{array}$ & Cell 12 & $\begin{array}{l}\text { Original polymer cement } \\
\text { concrete (PCC) }\end{array}$ \\
\hline $\begin{array}{l}\text { Cell } \\
113-513\end{array}$ & Thin concrete pavement & $\begin{array}{l}\text { Cell } \\
114-914\end{array}$ & $\begin{array}{l}\text { Whitetopping on distressec } \\
\text { asphalt }\end{array}$ \\
\hline Cell 15 & Warm mix asphalt (WMA) & Cell 16 & $\begin{array}{l}\text { Recycled unbound base, } \\
\text { WMA }\end{array}$ \\
\hline Cell 17 & $\begin{array}{l}\text { Recycled unbound base, } \\
\text { WMA }\end{array}$ & Cell 18 & $\begin{array}{l}\text { Recycled unbound base, } \\
\text { WMA }\end{array}$ \\
\hline Cell 19 & $\begin{array}{l}\text { Recycled unbound base, } \\
\text { WMA }\end{array}$ & Cell 20 & $\begin{array}{l}\text { fractioned recycled asphalt } \\
\text { pavement (RAP) }\end{array}$ \\
\hline Cell 21 & fractioned RAP & Cell 22 & fractioned RAP \\
\hline Cell 23 & $\begin{array}{l}\text { Warm mix asphalt } \\
\text { (WMA), taconite }\end{array}$ & & \\
\hline
\end{tabular}

TABLE 2. SUMMARY OF PAVEMENT SURFACE MATERIALS ON THE MNROAD LOW VOLUME ROAD (LVR)

\begin{tabular}{|c|c|c|c|}
\hline $\begin{array}{l}\text { Test } \\
\text { number }\end{array}$ & Material type & \multicolumn{2}{|c|}{ Test number Material type } \\
\hline \multicolumn{4}{|c|}{ South Loop (East to West) } \\
\hline Cell 54 & Mesabi hard rock, PCC & Cell 53 & Concrete initiatives \\
\hline Cell 52 & Concrete initiatives & Cell 32 & Concrete initiatives \\
\hline Cell 31 & Mesabi hard rock & Cell 79 & $\begin{array}{l}\text { Stabilized full depth } \\
\text { reclamation }\end{array}$ \\
\hline Cell 78 & $\begin{array}{l}\text { Stabilized full depth } \\
\text { reclamation }\end{array}$ & Cell 77 & $\begin{array}{l}\text { Stabilized full depth } \\
\text { reclamation }\end{array}$ \\
\hline Cell 28 & $\begin{array}{l}\text { Stabilized full depth } \\
\text { reclamation }\end{array}$ & Cell 27 & $\begin{array}{l}\text { Asphalt pavement, chip } \\
\text { seal }\end{array}$ \\
\hline Cell 89 & Pervious \&Porous HMA & Cell 88 & Pervious \&Porous HMA \\
\hline Cell 87 & Pervious \&Porous HMA & Cell 86 & Pervious \&Porous HMA \\
\hline Cell 85 & Pervious \&Porous HMA & Cell 24 & Aging study \\
\hline \multicolumn{4}{|c|}{ North Loop (West to East) } \\
\hline Cell 33 & Acid modified & Cell 34 & Acid modified \\
\hline Cell 35 & Acid modified & Cell 36 & Original PCC \\
\hline Cell 37 & Original PCC & Cell 38 & Original PCC \\
\hline Cell 39 & $\begin{array}{l}\text { Previous concrete overlay } \\
\text { of PCC }\end{array}$ & Cell 40 & Original PCC \\
\hline
\end{tabular}

\section{OPERATION PHASES OF THE MNROAD}

The MnROAD test road has conducted and completed researches of the project for two phases at present. The phase-I (1994-2006) was designed to evaluate and optimize the pavement design methods, pavement performance particularly for the resistance to freezing and thawing and low temperature susceptibility for the low-temperature regions; field verification of SUPERPAVE design system and SHRP asphalt binders performance grading (PG). The phase-I of MnROAD mainly focused on concrete and asphalt structural designs, including spring and winter load restrictions, mechanistic-empirical pavement design and low-temperature cracking ${ }^{[6]}$, as shown in Table 3. 
TABLE 3. MAIN RESEARCH AREAS OF THE MNROAD DURING PHASE-I AND PHASE-II [5]

\begin{tabular}{|c|c|}
\hline $\begin{array}{l}\text { MnROAD's } \\
\text { operation phase }\end{array}$ & Main research areas \\
\hline \multirow{6}{*}{$\begin{array}{l}\text { Phase-I } \\
(1994-2006)\end{array}$} & Spring load restriction policy \\
\hline & Winter load increase policy \\
\hline & Low temperature cracking reduction \\
\hline & $\begin{array}{l}\text { Mechanistic-Empirical (M-E) flexible design method } \\
\text { (asphalt) }\end{array}$ \\
\hline & M-E rigid design method (concrete) \\
\hline & Sealing pavement/shoulder joints \\
\hline \multirow{6}{*}{$\begin{array}{l}\text { phase-II } \\
(2007-2015)\end{array}$} & $\begin{array}{l}\text { Investigation of low temperature cracking in asphalt } \\
\text { pavements }\end{array}$ \\
\hline & $\begin{array}{l}\text { Development of an open graded aggregate base (stable } \\
\text { and drainable) }\end{array}$ \\
\hline & $\begin{array}{l}\text { Thin and ultrathin concrete overlays of existing asphalt } \\
\text { pavements }\end{array}$ \\
\hline & $\begin{array}{l}\text { Development of design guide for recycled unbound } \\
\text { pavement materials }\end{array}$ \\
\hline & $\begin{array}{l}\text { Full-depth reclamation stabilized with engineered } \\
\text { emulsion }\end{array}$ \\
\hline & $\begin{array}{l}\text { Field investigation of highway base material stabilized } \\
\text { with high carbon fly ash }\end{array}$ \\
\hline
\end{tabular}

The phase-II of MnROAD (2007-2015) was hosted and operated by the Traffic Engineering and Road Research Alliance (TERRA), funded through a combination of research and education groups, industry and international interests. Listed below are the five research aims during Phase II:

(1)Construction Innovation-advance new construction technology that maximize productivity,

(2)Green Road-effective use of recycled materials and other waste products such as taconite aggregates, fly ash, shingles etc. throughout the pavement structure,

(3)Pavement Preservation and Rapid Renewal-development and refinement of techniques to reduce pavement life cycle costs, and maximize investments for pavement long-term performance,

(4)Pavement Surface Characteristics-establish new techniques with our research cooperator for smooth, quiet, durable, safe and skid-resistant pavements,

(5)Non-Pavement Research-develop intelligent transportation systems through the use of MnROAD's unique facility[5].

The phase-III of MnROAD (2017-2026) is currently being planned to continue the previous two phases' research. The National Center for Asphalt Technology (NCAT) is one of the major partnerships, as well with other states. These researches will promote using of full-scale pavement testing facilities in both warm and cold climates on flexible, rigid, and composite pavement structures. There are two main areas of research focus: pavement preservation and pavement cracking performance tests. The goal of pavement preservation study is to quantify the life-extending benefits of different pavement preservation for roadways in different stages of life. The aim of conducting cracking performance testing study is to develop future technologies much more efficiently over a wide range of climate and traffic factors[6].

\section{CONCLUSIONS}

The MnROAD full-scale test road has attained great progress and made positive impacts within the state of Minnesota and the surrounding nation at large. For the phase I, it provided the construction experience about the pavement performance of cold regions, especially for the low-temperature cracking and the freeze-thaw damage. The research also verified the feasibility of the performance grade (PG) of asphalt binders. For the phase II, it tested and verified the Mechanistic-Empirical Pavement Design Guide (MEPDG) in cold areas, studied the damage model of low-temperature cracking, conducted the research containing Strategic Highway Research Program (SHRP) composite pavement, and proposed a series of advanced techniques that containing the new-type construction methods like intelligent compaction, pavement maintenance and pavement materials recycling technology. All these achievements can provide valuable experience on new-generation pavement materials and design method.

\section{ACKNOWLEDGEMENTS}

This work is supported by the National Natural Science Foundation of China (51508032), the China Postdoctoral Science Foundation Funded Project (2014M562360), the Natural Science Basic Research Plan in Shaanxi Province of China (2015JZ012), the Opening Funding Supported by the Key Laboratory of Road Structure \& Material, Ministry of Transport, Beijing (KF201402), the Opening Funding Supported by the Key Lab of Highway Construction \& Maintenance Technology in Loess Region, Ministry of Transport (KLTLR-Y13-11) and the Fundamental Research Funds for the Central Universities (310821163404). The authors gratefully acknowledge their financial support.

\section{REFERENCES}

[1] Li Shenglong. Asphalt pavement structural information monitoring and fatigue prediction, master'degree, Harbin Institue of Technology (2013).

[2] B.J. Worel, M.Jensen, T.R. Clyne. Economic benefits resulting from road research performed at MnROAD. 2008.

[3] B.J. Worel, D.V. Deusen. Benefits of MnROAD phase-II research. 2015.

[4] B.J. Worel, T. Andersen, R. Mulvaney. 1999 MnROAD SUPERPAVE tracking-low volume road cells 33-35. 2003.

[5] G. Engstrom, B.J. Worel. Safer, smarter, sustainable pavements through innovations research. 2015.

[6] D.V. Deusen, B.J. Worel. MnROAD phase II research innovations projected to save millions of dollars. 2015. 